\title{
Autumn crane migration and climate change in the Carpathian Basin
}

\section{ZSOLT VÉGVÁRI}

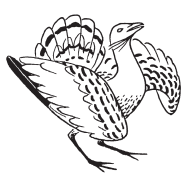

Zsolt Végvári 2015. Autumn crane migration and climate change in the Carpathian Basin. - Ornis Hungarica 23(2): 31-38.

programme performed in Hortobágy National Park since 1994 . As a result I detected consistently asymmetrical migration phenologies in Hortobágy, indicating a superposition of several migration waves. Cranes used nearly 60 roost sites in Hortobágy with the largest ones situated in extensive fishponds. In contrast, cranes migrating in Körös-Maros National Park started to overwinter regularly, increasingly roosting in dry wetlands. In Kiskunság cranes tended to stage for shorter periods than in Körös-Maros, with the largest flocks to be observed in Lake Fehér of Szeged fishponds and additionally in a number of alkali lakes. Cranes observed in the Borsodi Mezöség region are considered satellite flocks staging in Hortobágy, as shown by irregular fluctuations.

As a probable result of climatic variability, cranes migrating in Hortobágy have shown the advancement of first arrival dates and exhibited significant, positive relations with local mean monthly temperatures. Additionally, we detected a positive relationship between the Julian date of autumn migration peak and winter mean of the North-Atlantic Oscillation, indicating later autumn arrivals during warmer periods.

Keywords: Common Crane, migration, phenology, global climatic parameter, Hortobágy National Park

Összefoglalás A darvak éjszakázóhelyeken történő szinkronszámlálása 2006-2014 között történt minden nagyobb magyarországi daruátvonuló-helyen, az 1994 óta a Hortobágyi Nemzeti Parkban heti rendszerességgel folyó állományfelmérések kiterjesztéseként. A számlálások eredményeképpen a Hortobágyon konzisztens módon aszimmetrikus vonulásdinamika mutatkozott, ami több vonulási hullám szuperpozíciójára utal. Ezen a területen közel 60 különböző éjszakázóhelyet használtak a darvak, melyek közül a legnagyobbak halastavakon találhatóak. Ezzel szemben a Körös-Marosban átvonuló madaraknál rendszeressé váló áttelelés mutatkozott, melynek során egyre gyakrabban használtak a darvak száraz élőhelyeket. A Kiskunságban a darvak átlagosan rövidebb ideig tartózkodtak, mint a Körös-Marosban, ahol a legnagyobb csapatokat a Szegedi Fehér-tavon figyelték meg. A Borsodi Mezőségben átvonuló madarakat a rendszertelen állománynagyság-változások miatt nagy valószínüséggel a Hortobágyon mozgó csapatok szatellit-populációinak tekinthetjük.

Feltételezhetően a klimatikus paraméterek varianciájának növekedése eredményeként a Hortobágyon átvonuló darvak az első tavaszi érkezések dátumát korábbi dátumok irányába tolták, szignifikáns, pozitív kapcsolatot mutatva a helyi, havi átlaghőmérséklettel. Emellett pozitív, szignifikáns kapcsolatot sikerült kimutatni az öszi vonulási csúcsok julián-dátuma és az Észak-Atlanti Oszcilláció téli átlagértéke között, mely a melegedő őszi időjárás által indukált későbbi érkezésekre utal.

Kulcsszavak: daru, vonulás, fenológia, globális klímaindex, Hortobágyi Nemzeti Park

HNPI-DE Department of Conservation Zoology 4024 Debrecen, Sumen utca 2., Hungary, e-mail: zsolt.vegvari@ gmail.com 


\section{Introduction}

On ecosystem scales, various metrics of climatic processes have shown increasing variance during the past decades, inducing a broad range of ecological responsiveness (IPCC 2015). Specifically, phenological proxies, such as the start of plant blooming, are known to be sensitive to climatic processes (Peñuelas \& Filella 2001, Parmesan \& Yohe 2003, Macmynowski et al. 2007), with several phenological phases currently advancing as a response to recent climate change (Bradley et al. 1999). For instance, changes in timing of bird migration is predicted by plant and invertebrate phenologies (Sparks et al. 2005) - there are tendencies to migrate earlier in response to earlier springs in the birds' breeding range (Strode 2003, Crick 2004, Lehikoinen et al. 2004).

Common Cranes (Grus grus) breed in wooded bogs and wetland forests of northern Eurasia and exhibit various migration strategies. While the majority of the crane populations are classified as short-distance migrants based on the results of satellite tracking, some subpopulations, such as those inhabiting the European part of Russia, proved to be long-distance migrants. Furthermore, satellite tracking of several Common Cranes nesting in Finland followed loops connecting Northern Europe, Hungary, Tunisia, Morocco, Spain and Germany. Interestingly, cranes that have recently started to breed in the British Isles are sedentary (Prange 1999).

Common Cranes breeding in Europe and west of Russia migrate along at least four flyways:

(1) the Atlantic Flyway connects the breeding grounds of Sweden, Norway and Germany with the wintering areas in France and Spain,

(2) Cranes breeding in Finland, the Baltic States and Poland use the Baltic-Hungarian
Flyway to spend winter in Serbia and Northeast Africa as far south as Sudan and Ethiopia; at their stopover sites in Hortobágy they roost in flocks of up to 55,000 birds (Prange 1999, Végvári \& Tar 2002),

(3) Cranes of the East-Baltic Region possibly migrate over the Black Sea and Turkey and spend the winter in Israel with some of them flying to Ethiopia covering ca. 4000 $\mathrm{km}$,

(4) populations of the European part of Russia migrate across the Black Sea and winter in Turkey, Israel and Ethiopia.

The Hortobágy National Park (HNP) is known as the largest stop-over site of the Common Crane in the Baltic-Hungarian Flyway in Europe (Prange 1999), as the peak number of simultaneously roosting cranes during autumn migration has increased from 3000 to 140,000 from $1980-2015$. Further, this region is probably the second largest staging of cranes in the world, exceeded only by Nebraska, which hosts up to 500,000 Sandhill Cranes during spring migration (International Crane Foundation 2015). Although regular wintering has not yet been observed in the study area, the frequency of wintering in the southern part of the country has been increasing since 2000 (Végvári unpublished data). As part of an active wetland management system, water depth is kept shallow all year on seven marshes and in one of the largest fishponds to attract cranes for roosting.

\section{Methods}

\section{Study area}

We conducted standardized, simultaneous weekly survey in all known staging areas of Common Cranes within the Carpathian Basin between 2006-2015 during 
autumn migration, covering the Hortobágy, Körös-Maros, Kiskunság, Bükk and FertöHanság National Parks in Hungary.

\section{Autumn migration data}

Weekly simultaneous censuses were performed during autumn migration and wintering with the help of a large number of experienced volunteers between 2006-2015. Arriving cranes were counted simultane- ously once a week at all potential roost sites (marsh or fishpond) during the autumn migration period from $10^{\text {th }}$ September to $31^{\text {st }}$ December. Potential roost sites were identified weekly 2-3 days before the day of the count. Based on previous studies, only wetlands with minimum area of 3 ha and water depth $40 \mathrm{~cm}$ or less (Végvári \& Tar 2002) could be considered as potential roosting sites. If a potential roosting site was used by

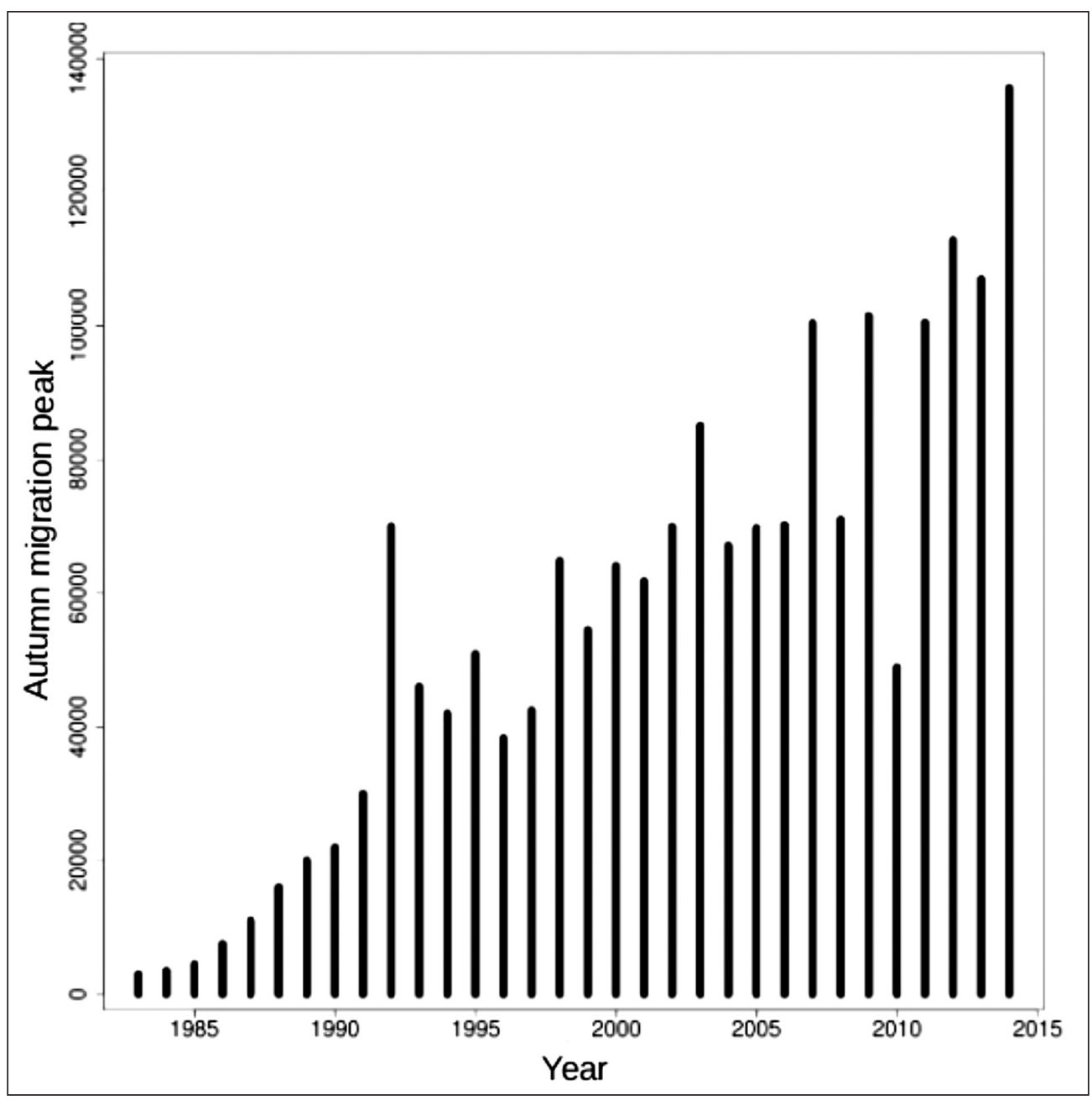

Figure 1. Annual peak numbers of migrating cranes as counted simultaneously in the whole of the Carpathian Basin

1. ábra A Kárpát-medencében szinkronszámlálások alapján együttesen átvonuló darvak évenkénti száma 


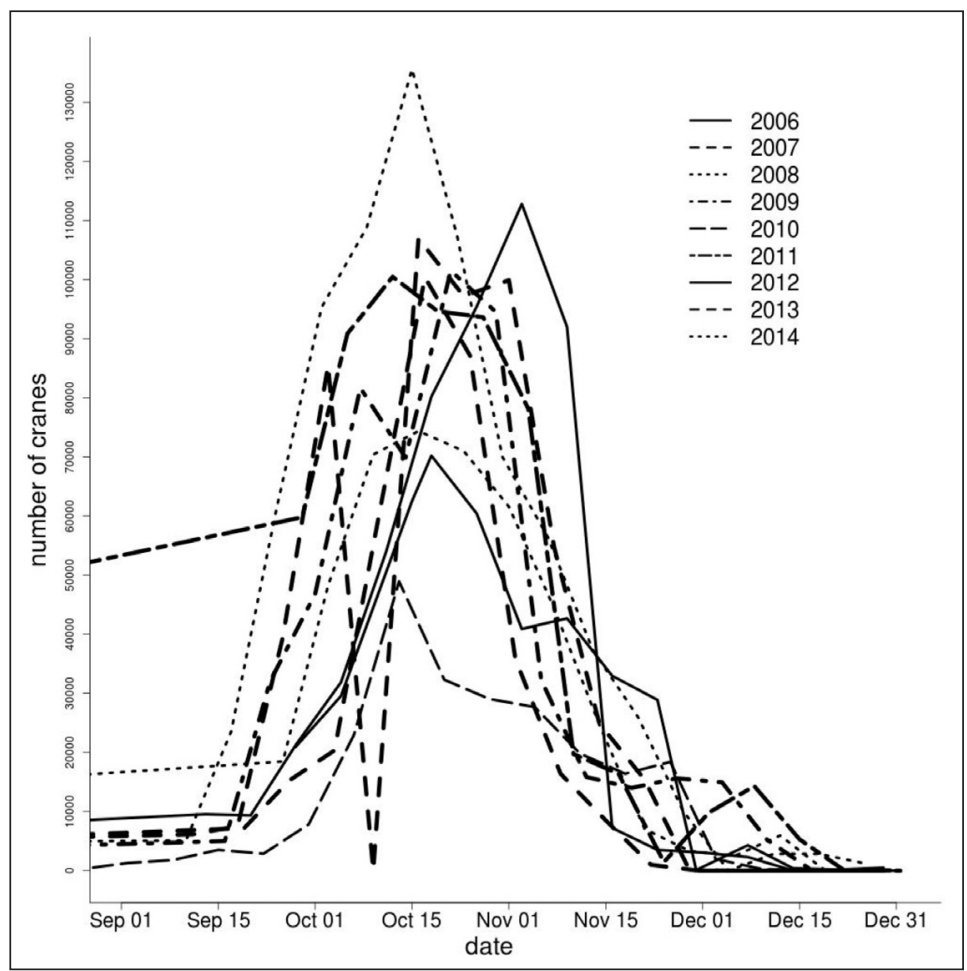

Figure 2. Phenology of autumn crane migration in Hortobágy

2. ábra Az őszi daruvonulás fenológiája a Hortobágyon

Figure 3. Phenology of autumn crane migration in Körös-Maros

3. ábra Az őszi daruvonulás fenológiája a Körös-Maros térségében

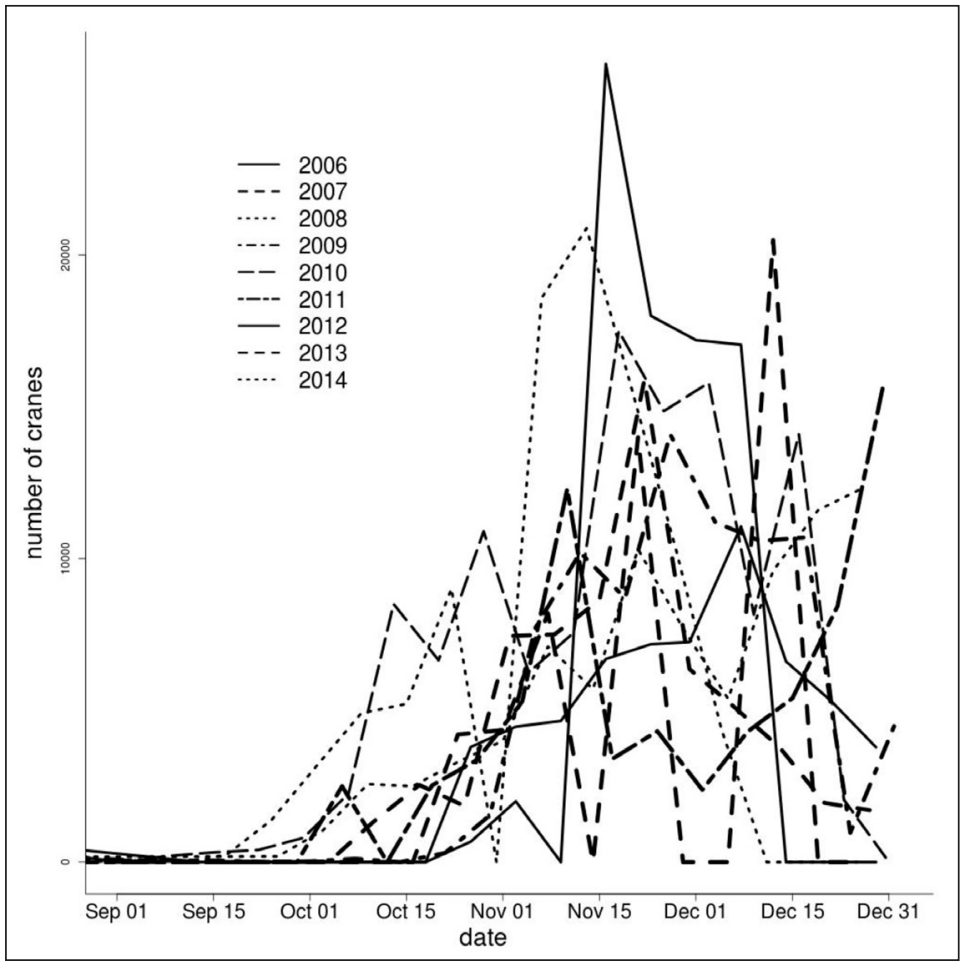


Figure 4. Phenology of autumn crane migration in Kiskunság

4. ábra Az őszi daruvonulás fenológiája a Kiskunságban
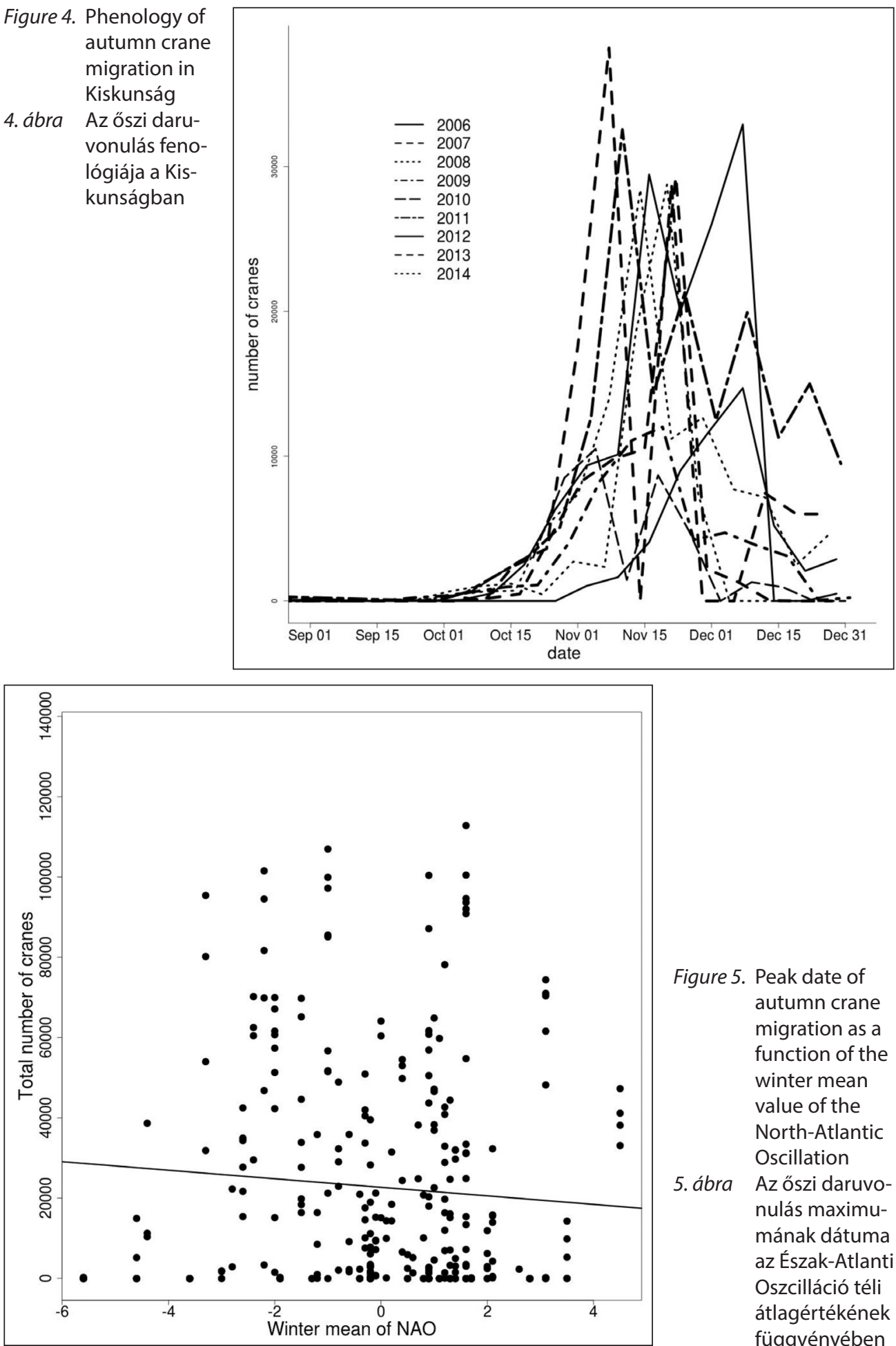

Figure 5. Peak date of autumn crane migration as a function of the winter mean value of the North-Atlantic Oscillation

5. ábra Az őszi daruvonulás maximumának dátuma az Észak-Atlanti Oszcilláció téli átlagértékének függvényében 
cranes, it was classified as an actual roosting site. To avoid double-counting on each count day counters simultaneously surveyed 2-16 active sites where cranes were present. Roosting counts started two hours before sunset and took three hours, applying roosting count methods suggested by Marsh and Wilkinson (1991), Prange (1999) and Alonso et al. (2004). Counts were performed from bird observation blinds or from one to four elevation points at each roost site to survey all flocks arriving from different directions. Surveys were conducted using $8-10 \times$ binoculars, and $20-60 \times$ as well as $32 \times$ spotting scopes.

\section{Results}

\section{Regional migratory movements}

As shown on Figure 1, total counts have non-linear increasing trend with major fluctuations. However, the number of data points is still too low for robust statistical analyses.

\section{Hortobágy}

Migration trend in the region is shown by Figure 1, exhibiting a consistent temporal pattern between years. Trends are typically asymmetrical, where arrival slopes are significantly smaller than departure estimates. Besides, trend shapes suggest a superposition of several migratory waves, the peak dates of which show a non-significant increasing trend $(b=595.0, p=0.07)$. The largest roost sites are found in artificial fishponds with substantial human disturbance. Additionally, cranes staging in Hortobágy roost in dry meadows or marshes with an increasing frequency, implying low predation pressure in the area.

\section{Körös-Maros}

Population trends in the roost sites of the region are shown by Figure 2. As compared to the size of the region, cranes choose more than 20 roost sites. In parallel to trends observed in Hortobágy, cranes frequently roost in dry or frozen wetland, especially during the wintering period. The peak dates of annual migration trends show a significant increasing trend $(b=1375.7, p=0.012)$.

The region has become part of the regular wintering site of the North-Voivodina region, as a result of warming winters (Stumberger \& Schneider-Jacoby 2010).

\section{Kiskunság}

Trends observed in the region are shown by Figure 3. Part of the crane flocks migrating from Hortobágy stage in Kiskunság, exhibiting sharper migratory peaks than those of Körös-Maros. The peak dates of annual migration trends show a non-significant increasing trend $(b=1874.3, p=0.164)$. The largest roost sites of the region are located in Lake Fehér of Szeged with numerous flocks showing up in alkaline ponds.

\section{Bükk}

Although cranes migrating in Borsodi Mezőség region roost in wetlands within the administration district of the Bükk National Park Directorate, these flocks are probably satellite populations of the Hortobágy stopover site, as shown by intensive fluctuations (due to irregular movements, map not shown).

\section{Fertö-Hanság}

Although the region is characterised by low numbers of migratory flocks, the isolation of the site and the close vicinity of the Czech breeding population indicates that cranes observed here join flocks migrating 
from the Czech Republic which follow the Atlantic Flyway crossing Germany (due to irregular movements, map not shown).

\section{Climatic effects}

\section{Autumn migration and climate}

We detected a significant, positive relation between peak date and monthly NAO $\left(\mathrm{r}^{2}=0.407, \mathrm{p}=0.019\right)$ (Figure 4). The relation of the time difference between the timing of peak and median with the monthly mean of local minimum temperatures were also positive $\left(\mathrm{r}^{2}=0.369, \mathrm{p}=0.028\right)$.

\section{Discussion}

I detected a strong population increase of the Common Cranes staging in Hortobágy during the study period. This development which shows highly similar patterns with the development of total migrating population parallels the increase observed along the Atlantic Flyway, which corresponds to the increase of breeding populations throughout Europe (Prange 1999). Recently, a hypothesis has been put forward arguing that population growth in the Common Crane might be partially driven by a warming climate in Northern Europe resulting in the northward shifting of the permafrost zone. However, this prediction has not been tested.

Findings of the current work confirm the explosion of the European population, as the peak number of cranes exceeded a magnitude of 100 thousand birds, thus classifying Hungary and Hortobágy the largest stopover site of cranes (Végvári et al. 2010). Our results indicate loop migration of crane passing Hungary: crane flocks tracking the Baltic-Hungarian Flyway in autumn migrate across Algeria and Morocco following the Atlantic
Flyway during spring migration. As alternating movements between flyways might be a regular element of migration strategy in the European crane populations, it cannot be excluded that years with unexpectedly high autumn peaks indicate the influx of populations breeding in Northwest Russia.

Additionally, migration data indicate that cranes observed in Fertö-Hanság region constitute part of the Czech population tracking the Atlantic Flyway. Further, migration records imply that part of the flocks migrating in South-Hungary fly across Italy and winter in France.

This work revealed that an increasing number of cranes spending winter at Hortobágy might indicate a general shift of the wintering grounds northwards, as has already been detected along the Atlantic Flyway (Prange 1999). Similarly, our findings indicate that cranes migrate earlier after warmer winters, suggesting the northward shift of the northern border of the wintering area.

I showed that the peak date is shifting later for autumn migration as a response to increasing NAO values typical for wetter and warmer climates. Similarly, we detected a delayed arrival of flocks arriving after the date of the median value, implying a delayed fall migration due to warmer conditions in the northern part of Europe. Summarizing, Common Cranes might benefit from global warming like many other short-distance migrants do, by increased survival rates during winter and earlier arrivals on the breeding grounds.

Although in Europe the Common Crane is not endangered and possibly benefits from global warming, its roosting sites in staging areas may be significantly reduced in the near future by human-induced and climate-related wetland losses, especially in southern Europe. However, there are indications that the West-Siberian population wintering in India 
may be declining probably as a result of wetland loss and structural changes in agricultural technology on the wintering grounds (Meine \& Archibald 1996, Végvári \& Hansbauer 2009).

Although the Common Crane is not threatened in Europe, it is considered an umbrella species and thus improving conditions for crane migration needs to be considered when developing management plans. On the one hand, it is recommended to be prepared for the increase of the wintering population owing to warming winters, which affects the practice of the management of native wetlands and

\section{References}

Alonso, J. C., Bautista, L. M. \& Alonso J. A. 2004. Family-based territoriality vs. flocking in wintering Common Cranes Grus grus. - Journal of Avian Biology 35(5): 434-444. DOI: 10.1111/j.09088857.2004.03290.x

Bradley, L. N., Leopold, A. C., Ross, J. \& Huffaker, W. 1999. Phenological changes reflect climate change in Wisconsin. - Proceedings of the National Academy of Sciences USA 96: 9701-9704. DOI: 10.1073/pnas.96.17.9701

Crick, H. Q. P. 2004. The impact of climate change on birds. - Ibis 146(Suppl.1): 48-56. DOI: 10.1111/ j.1474-919X.2004.00327.x

International Crane Foundation 2010. http:/www.savingcranes.org/ (last visited: 11-05-2010).

Lehikoinen, E., Sparks, T. H. \& Zalakevicius, M. 2004. Arrival and departure dates. - Advances in Ecological Research 35: 1-31. DOI: 10.1016/S00652504 (04)35001-4

Macmynowski, D. P., Root, T. L., Ballard, G. \& Greupel, G. R. 2007. Changes in spring arrival of NearcticNeotropical migrants attributed to multiscalar climate. - Global Change Biology 13: 2239-2251. DOI: $10.1111 /$ j.1365-2486.2007.01448.x

Marsh, C. P. \& Wilkinson, P. M. 1991. The significance of the central coast of South Carolina as critical shorebird habitat. - Chat 54: 69-92.

Meine, C. D. \& Archibald, G. W. 1996. The cranes: status survey and conservation action plan. - IUCN, Gland, Switzerland, pp. 1-207.

Parmesan, C. \& Yohe, G. 2003. A globally coherent fingerprint of climate change impacts across natural systems. - Nature 421: 37-42. DOI: 10.1038/nature 01286 fishponds. In parallel, the harmonisation of agri-environmental schemes and management plans is required on the other hand.

\section{Acknowledgements}

Special thanks go to the ranger services of HNPI, KMNPI, KNPI, BNPI, FHNPI National Park Directorates, as well as to the members of the following NGO-s: Hortobágy Society for Conservation, Birdlife Hungary, members of Zöld Kör, Bakcsó and many citizen ornithologists for data collection.

Peñuelas, J. \& Filella, I. 2001. Responses to a warming world. - Science 26: 793-795.

Prange, H. 1999. Migration of Common Crane Grus grus in Europe. - Vogelwelt 120: 301-305.

Sparks, T. H., Bairlein, F., Bojarinova, J. G., Hüppop, O., Lehikoinen, E. A., Rainio, K., Sokolov, L. V. \& Walker, D. 2005. Examining the total arrival distribution of migratory birds. - Global Change Biology 11: 22-30. DOI: 10.1111/j.13652486.2004.00887.x

Strode, P. K. 2003. Implications of climate change for North American wood warblers (Parulidae). - Global Change Biology 9: 1137-1144. DOI: 10.1046/j.1365-2486.2003.00664.x

Stumberger, B. \& Schneider-Jacoby, M. 2010. Importance of the Adriatic Flyway for Common Crane (Grus grus). - Proceedings of the $7^{\text {th }}$ European Crane Conference, pp. 14-17.

Végvári, Z. \& Tar, J. 2002. Roost site selection of the Common Crane Grus grus in the Hortobágy National Park, Hungary between 1995-2000. - Ornis Fennica 79: 101-110.

Végvári, Z. \& Hansbauer, M. M. 2009. Cranes in northern India. - unpublished report on a pre-study trip in January 2009. Report for Kranichschutz Deutschland and International Crane Foundation, pp. 1-11.

Végvári, Z., Bókony, V., Barta, Z. \& Kovács, G. 2010. Life history predicts advancement of avian spring migration in response to climate change. - Global Change Biology 16: 1-11. DOI: 10.1111/j.13652486.2009.01876.x 